\title{
THEM DAYS: LIFE ON AN ABORIGINAL RESERVE 1892-1960
}

\section{Lynne Hume}

Historically, the interests of Aboriginal people in Queensland have been subjugated by those of the white majority. This has resulted in a degree of powerlessness which is alien to non-Aboriginal Australians and therefore perhaps, difficult for them to comprehend. The history of the European colonisation of Australia has been mostly recounted in the literature from a non-Aboriginal perspective. With a few exceptions ${ }^{1}$ we have heard little of the history of contact in Australia from an Aboriginal point of view, and even less of the effects of missionisation. A notable exception to the latter is the recently published book by Swain and Rose $^{2}$ dealing with Aborigines and Christian missions.

This paper will give an account of the history of an Aboriginal community in far north Queensland (Yarrabah) using as primary source material, archival material and oral accounts from old people living today who remember what it was like to grow up on a mission. The use of both historical sources and personal narratives lends credence to both as they tend to feed back into one another. Such an approach helps to guard against bias from one person's account and reduces the chances of distortion.

The period covered is 1892 to 1960 , from the year of the founding of the mission to the year when it became a government reserve. During this time the Aboriginal inhabitants of Yarrabah attempted various strategies of resistance to European domination; most were responses to changing missionary and government policies.

\section{The foundation era: humble beginnings}

Yarrabah is now (1986) an Aboriginal reserve in coastal far north Queensland. It was established in 1892 by the Reverend John Brown Gribble, an Anglican minister intent upon bringing the word of God to Aborigines. John Gribble had founded missions on the Murrumbidgee in New South Wales, and on the Gascoyne River in Western Australia, but his zeal for justice for the Aborigines in Western Australia had stirred up resentment and hostility among many white settlers in that region, especially when he attempted to expose atrocities perpetrated on Aborigines by Europeans. Opposition to his mission from local whites escalated and Gribble was forced to leave the area for his own safety after two attempts had been made on his life. By order of the Government of Western Australia he was smuggled out of the State at night, under strong police escort; he then tumed to parish work in New South Wales.

Baron von Mueller, the Victorian Government botanist, first drew J.B. Gribble's attention to the possibilities of opening an Aboriginal mission near the Bellenden Ker Ranges in North Queensland. Gribble explored the north of Queensland, using money from

Lynne Hume received her Ph.D. degree at the University of Queensland in 1990. Her fieldwork at Yarrabah was undertaken in 1985-1986. She has also carried out fieldwork in Melanesia (Vanuatu), focussing on women, traditional religion and Christianity. Other areas of interest include cross-cultural communication, social change and applied anthropology.

1 Gilbert 1977 and Rosser 1977, 1985.

2 Swain and Rose 1988. 


\section{THEM DAYS}

his insurance policy to pay for the fare. When he had decided on a possible area, he met with members of the Diocesan Council of North Queensland in 1891 to seek their approval to his plan, stating that he had persuaded the Queensland Govemment to grant an Aboriginal reserve at Cape Grafton. The Australian Board of Missions (the official missionary organ of the Anglican Church in Australia) advised Gribble that it would recognise the proposed mission as a Church mission, but that he would have to raise the initial funds for its establishment. The Government of Queensland promised support; and, after consideration, the Diocese of North Queensland also approved the project, establishing a fund which would provide $£ 200$ per year. Thus began a partnership of three interests: the Australian Board of Missions, the Diocese of North Queensland, and the Government of Queensland. With official permission granted, Gribble landed at False Bay on 17 June 1892, the site of the present community. ${ }^{3}$

Gribble proceeded to clear land, build a mission house, establish vegetable gardens and explore the area for future agricultural and livestock developments, in preparation for his first Aboriginal converts to Christianity. Assisting John Gribble were three helpers: Pearson, Willie Ambrym (a South Sea Islander) and Pompo Katchewan. ${ }^{4}$ The Aborigines native to the area were the Gungandji, but during John Gribble's time, none came in to the mission.

Malaria prevented John Gribble from continuing his work and within a few months of his venture's auspicious beginnings he became so ill that he had to leave the mission, and died in Sydney on 3 June 1893, at the age of forty-five years. ${ }^{5}$ At John Gribble's request, his son, Ernest, a young man of 24 years, replaced him and remained at Yarrabah until 1908 when he also left due to ill health. 6 When Ernest arrived in October 1892, in response to his father's call for help, he found only a tent and a small shed made of sapling walls and an iron roof, an unfinished two-room cottage. ${ }^{7}$ Although John Gribble had spent months of hard labour preparing the mission site, he had been unable to attract any possible converts.

Emest renamed the Bellenden Ker Mission 'Yarrabah'. ${ }^{8}$ Convinced, like his father before him, that Aboriginal people could only benefit by conversion to Christianity, he set about looking for converts.

The first choice open to Aborigines in the Cape Grafton area was to ignore the mission completely. This they did for some time. Because of his lack of immediate success at attracting the local inhabitants to the mission, Ernest, accompanied by Willie Ambrym, took a boat up the Barron River in search of possible recruits from the Aboriginal camps

3 The Diocese of North Queensland Yearbook 1959.

4 An Aboriginal youth from North Queensland whose exact origin is unknown. Pompo was taken from his people by force when an infant and brought up by the Swallow family of Hambledon until he was about 12 years old. He was given to the Simmonds family and later passed on to the Reverend J.B. Gribble (ABM Archives, Mission Notes, Box 1, Folder 1).

Gribble 1930:58.

Gribble 1933:44.

Gribble 1930:56-57.

8 Gribble (1933:34) writes that the word 'Yarrabah' was taken from the local Aboriginal word Eyerraba, meaning 'meeting place', so called because of the trading canoes calling there for barter and sale of local goods. However there are other interpretations on the origin of the word; one is that it comes from JunJun Yarra, an Aboriginal word for 'fishhawk', which eventually became Yarra-burra, and then Yarrabah (Walkabout, 1 July 1955:). 
along the river. He also travelled over the Cape Grafton area, stopping at camps and giving out flour, tea, sugar and tobacco as a gesture of goodwill. It took several months for the first Aborigines to arrive at Yarrabah, but with a few enticements, they did so voluntarily. Soon the local Gungandji people began to come in for the food and tobacco offered, and some of the men informed Ernest that they would bring some children and old women to the mission. On 10 December 1892, eight Aboriginal men and a dozen women and children attended morning prayers. On 18 December 1892 , there were forty Aborigines at the church service. By 26 January 1893, a few children began staying at the mission overnight instead of returning to their camps. ${ }^{9}$

Life at the mission in the early 1890's was not easy. Sicknesses such as malaria and rheumatism prevented those who could be of assistance from being productive, sometimes for long periods, and bad weather with constant heavy rains hampered progress. Some of the introduced domestic animals such as cows and horses were attacked by crocodiles. Trees had to be felled and scrub cleared to establish farming land for the planting of potatoes, melons and other vegetables. Fences were built and timber cut for the construction of houses and furniture. Daily morning and evening prayer services were conducted and the children's school started.

However, this was not enough to satisfy the Diocese of North Queensland who expected more converts. The Diocese of North Queensland had formed a committee in Townsville to support the new mission, but because, according to their expectations, so little had been achieved the committee decided at the end of 1893 that the mission should be closed and that Emest Gribble would have to be responsible for all future debts incurred. Gribble contacted the Primate in Sydney who asked him if he could carry on with a

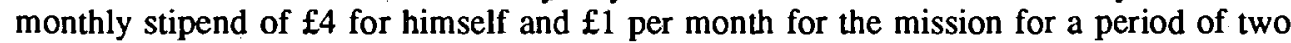
years. Gribble agreed. Hence, Yarrabah became an Australian Board of Missions mission, extra-diocesan to the Diocese of Sydney, and remained so until 1908. Thereafter it again became the responsibility of the Diocese of North Queensland. The Government provided a small subsidy after 1896. Gribble was determined not to let financial difficulties force him into abandoning what his father had begun, and he stayed at the mission until 1908. ${ }^{10}$

Among the first Aboriginal people to voluntarily visit the mission was Menmuny. ${ }^{11}$ When Menmuny first arrived he had three wives (all sisters) and several children. He later gave up two of his wives when he joined the mission and became a communicant. These two women subsequently married other men. By 1895 there were one hundred and twelve people living at the mission.

In its very early days (1892-1908) Yarrabah was regarded as a highly successful mission and a model for others. The Protector of Aborigines for the North of Queensland praised Yarrabah under E. Gribble, saying that the 'blacks' had been converted into 'sober, steady, trustworthy and hardworking men'. 12 Dr Roth described Yarrabah people as 'healthy, wellbehaved, industrious and progressing in all the common arts of civilised life' ${ }^{13}$ In 1898 , only six years after its foundation as a mission, Yarrabah was visited by the Home

9 ABM Archives, Gribble's journals, 26 January 1892, Box MS 1515/1, Item 2.

10 Feetham and Rymer 1929:55.

11 Gribble described him as 'king of this division of the Goon-gan-gee tribe' and later bestowed on him the title of 'King John'. (ABM Archives, Gribble's journals, 31 January 1893, Box MS 1515/1, Item 2.)

12 Extract from Missionary Notes, 24 April 1901 (quoted in Gribble 1933:46).

13 From Australian Christian World, 20 December 1902 (quoted in Gribble 1933:47). 


\section{THEM DAYS}

Secretary of Queensland, Colonel Foxton. Foxton had been visiting all the missions in the north and in Torres Straits and was so pleased by what he saw at Yarrabah that he asked Gribble to allow missionaries from the northem areas to study his methods. Foxton assured Gribble that Yarrabah stood above all the other mission stations for results in spite of its being such a young mission station. ${ }^{14}$

Before 1897, the mission served mainly local Gungandji people and others from nearby surrounding areas. Yarrabah settlement gradually expanded as more living huts, a school, a workshop, gardens and small villages away from the main village, emerged. The satellite villages were managed by the people who lived in them; the main village was managed by a council made up of confirmed Christians elected by the people, and mission staff.

\section{Institutionalised care and control}

The neo-Darwinian notion of social evolution, with Europeans being at the apex of the pyramid, permitted the belief that 'half-caste' children must be saved from their uncivilised (black) parent and brought together in an institutional setting. 'Half-caste' children, usually the product of a white male and an Aboriginal female liaison, were plucked from their mothers by mounted police protectors and forcibly sent to reserves and missions. There are old people at Yarrabah today who remember clearly the forcible separation from their mothers. One elderly man ${ }^{15}$, the son of an Aboriginal woman and a European father, remembers being taken by 'troopers' (mounted police), hand-cuffed to other children and taken to Port Stewart from his home town of Coen. He and others travelled by horse and buggy to the coast, and from there to Cooktown where they stayed in the police watchhouse for a night before being transported by ship to Yarrabah mission:

The police used to come along and grab all the half-castes... the kids in the camp, they used to grab 'em... take us all away from our parents. White people and coloured people couldn't agree with one another them days. They wanna take all the half-caste babies all along the coast.

A complete separation of blacks and whites was thought to be beneficial to both races: for the protection of Aborigines from the physical and moral ills of civilisation and unscrupulous whites, and for the protection of the 'purity' of whites:

The native is very susceptible to all the physical and moral ills of our civilization and it is only by complete separation of the two races that we can save him from hopeless contamination and eventual extinction, as well as safeguard the purity of our own blood. It is estimated that half the Aborigines of this state [Queensland] are half-castes which indicates that they have already suffered an infusion of white blood, and it is indisputable that the European population must, in the process, have also been contaminated to an extent sufficient to warrant serious reflection. 16

Under what was ostensibly humanitarian legislation, children were legally abducted from their kin by police officers, transported hundreds of miles away from their birthplaces and put under the control of well-meaning missionaries intent on Christian indoctrination and on bestowing the benefits of civilisation, as they perceived both. No consideration was given to the distraught family from whom they were abruptly separated. There were, however, some Europeans who openly declared their dislike of this practice. Some Cairns

14 Feetham and Rymer 1929:57.

15 Thomas Allen, of Caims, now deceased.

16 Queensland Parliamentary Papers, Annual report of the Chief Protector of Aborigines, 1920, vol.2:233. 
residents voiced their disapproval in letters to the editor of the local newspaper ${ }^{17}$ but their protests were in vain.

When the Lutheran mission on the Bloomfield River closed in 1901, the superintendent brought all his mission children to Yarrabah. In 1904, the Fraser Island mission was closed and Yarrabah was asked to receive its inhabitants. Gribble went to the island to effect the closing down of the mission and accompany its one hundred and seventeen people to Yarrabah. ${ }^{18}$ One woman ${ }^{19}$ who was transferred from the Fraser Island mission recalls:

We come on the big steamer. Gribble used to visit Fraser at different times...

Father Gribble. The last time he came we knew he wanted to shift the people.

From Fraser... to take us to Yarrabah. But some of the people wouldn't come.

They ran away... The grown-ups. They took their children too. I was about five [years old] when I came to Yarrabah. Father Gribble come to get us... all the Fraser Island people.

We used to see whales. We seen the whales spouting up ya know. When somebody see that they come back and take us all up at the stern and show us the whales spouting up. I don't know how long it [the voyage] took. She anchor way out fronta Green Island there. And the launches from Yarrabah came to take the people. Like us. We children all go to dormitory... Mama Gribble used to look after us.

When we got used to Yarrabah it was all right. Because we had Mumma Gribble to go and see all the time. Like we was happy when we had her. She used to look after us when we was sick.

Father Gribble's sister, Sister Ethel was the teacher. And the dormitory lady was Sister Helen. When Father Gribble left, they never make a big party or anything like that. They just went away quietly. Mrs O'Reilly went first. She went to Sydney, take her children. Then Father Gribble went later.

Fraser Island people were not at all happy at Yarrabah. Several attempts were made by various Fraser Islanders to escape, but they were always returned. With the addition of the Frazer Island people, the Aboriginal population of Yarrabah rose to 317; more than half were children.

The segregated dormitory system was in existence from 1895 . The boys' dormitory was a rectangular building with a concrete floor where the boys slept on a raised platform with blankets. The girls' dormitory was a wooden building, with a wooden floor, on which the girls slept with their blankets. ${ }^{20}$ Very young children who arrived at the mission, knowing no-one, were put straight into the dormitory. A Yarrabah woman remembered this time:

I went to the dormitory when I was about 7 years of age. We taken away from our mother... they used to take us away from our mother see... Our matron was very strict to us... we used to go every morning and evening to church... Many children were sent to Yarrabah alone with no adult parent or relative to look after their interests:

You got no parents. You got no parents to fight for ya. You just got to live.

You got no mother... father... or relatives to stand by you. Not like today. ${ }^{21}$

17 The Cairns Post, 6 October 1910.

18 Rowland 1960:94.

19 Mrs May Smith, of Cairns.

20 Wandandian (Richard Dyott) 1912:135.

21 Thomas Allen, of Cairns. 
Dormitories always held more girls than boys. In 1934 dormitory girls numbered at least 100 but there were only 34 boys. Girls remained in the dormitory until they were married, while boys left at age sixteen, at which time they built their own wooden-framed, grass-thatched huts, to be ready for the time when they married. Girls who had mothers at Yarrabah, usually stayed with them until they were about eleven or twelve years of age before being put into the dormitory. The matron accompanied the girls to church each morning and evening and carefully supervised their every move. There was very little mingling of the sexes, even outside the dormitories.

The mission dormitory system was common in many parts of Australia. Trigger 22 writes that it existed at Doomadgee in north Queensland; Brady and Palmer ${ }^{23}$ also mention the separation of 'half-caste' children from 'full-blooded' Aborigines and the existence of a dormitory system at Ooldea (South Australia); and the Roper River mission in the Northern Territory, established in 1908 , housed children in dormitories. ${ }^{24}$

When girls arrived at the mission their hair was cut in the short style required by the staff. The clothes that the children wore in early mission times were uniform: sulus ${ }^{25}$ and shirts for the boys, and dresses for the girls:

We used to have a dress in the dormitory, three button at the back, it's a yoke. Yoke dress. Blue dress for school, another blue dress for church. Three dresses, we had. A white one for Sunday, two blue ones - one for church and one for school. The dresses had three buttons at the back. No one was allowed to wear shoes. Mustn't have a shoe on ya feet, or hat. No hat, no shoes.

When a new lot come in from outside they dress with shoes and hat. Well they gotta strip off and go up to the mission house and get sulu and shirt. Father Gribble tell 'em go up to the mission house. That's where he keep the clothes. The mission house wasn't far from the dormitory. Our dormitory was there and the mission house was over here. They never have shoes till $\mathrm{Mr}$ McCullough came in to the mission. ${ }^{26}$

Children were expected to carry out various chores:

We used to go down to the sawmill and get sawdust to put on for the toilet. Cleaning the toilet. Me and my partner had to go down to the mill to get the sawdust in a bag and put that in a different bucket in the toilet. We used to go down and get wood there too, for the dormitory stove. You all have to go down and carry wood up in your arms for the dormitory. 27

Although the children were put directly into dormitories, adults who came from specific regions tended to congregate together:

Ya see, when they took there... they keep to their tribe. Like, if there's a dance, the Fourmile will have their own dance. They don't mix with any tribe. Our lot, Kubbi, they'll have their own dance too. A lovely dance. I used to think it's wonderful. Our tribe, you know there's a tribe in every coloured peoples... you know. Well, our tribe was Bundaberg. On the Bumett River.

22 Trigger 1988:222.

Brady and Palmer 1988:238.

24 Harris 1988:415.

25 A wrap-around strip of cloth tucked around the waist.

26 Mrs May Smith.

27 Mrs Tottie Joinbee, of Cairns. 
That name is from us. The language was Kubbikubbi, I think. I used to understand the language when they talk, but I never speak it. ${ }^{28}$

Some of the adults stayed in tents until they moved to the different settlements for married couples and families. One woman describes the mission in those early days:

We had all the streets and everything when we was there. It was set out like a mission station. All the couples had their houses. Tin roof and timber wall. Cupboards. We saw all that round. Father Gribble had them all set out good. A big school, and a big church. And the big hospital up the hill. The dormitory was upstairs and downstairs. A big place. Father Gribble's house was a big place - upstairs and downstairs. And Mumma Gribble [Emest Gribble's mother] had her cottage further down the street.

The school that I went to wasn't far from the beach. We boys and girls used to have schooling together first, in the small baby classes, then when we were grown up, boys had school in the morning and girls in the afternoon. The boys, when they were about 16 or 17 years old would leave the dormitory and go out in the village to work in different settlements. The boys would live in the big dormitory, then they have their own home which they built themselves before they got married.

I used to like Father Gribble. We used to take his morning tea down to... pick cotton... he picked cotton... he had fields of it. And we have to go down and take his tea. He'd give us half of his bread. We used to like that! He'd drink his tea and say, you girls can have the bread. We shared it... two girls. $\mathrm{Me}$ and another girl.

He used to come out Sunday morning and he'd talk to the children. $\mathrm{He}$ said, all the children, come over to me. And there was a coconut tree... We line up in two's and we have to say something. You know what we got to say? 'I must not steal, I must not tell lies. I must not say bad word this day'. You gotta say that every Sunday morning, all the children. Then he'd say: 'go on home'.

Father Gribble used to give the Black Tom. That's a stick what he keep in his study. It's a Black Tom. It give you cuts in the hand. Everybody used to talk about it... like tease one another, say, you go to office, you get the Black Tom. Father Gribble was good to the children. Very good. He used to give the cane, but he was a very good man. 29

Ernest Gribble's disciplinary tactics verged on military style punishments for small misdemeanours and were at times extremely harsh. He sometimes horsewhipped offenders, as he did with Pompo in 1893, because Pompo had given bread away to a 'camp black' against Gribble's express orders. Boys found eating earth were given castor oil; if found wearing Sunday clothing during the week, children were given pack drill. Girls were locked up for rudeness until penitent. Anyone found running away, or even heard making plans to escape was given the 'strap'. Some absconders were returned and chained up, only to attempt another escape:

Willie Williams absconded early this morning, he was chained up as usual but effected his escape by breaking or picking the lock. 30

30 ABM Archives, Gribble's journals, 20 August 1904, Box MS1515/2, Item 9. 


\section{THEM DAYS}

Anyone showing disrespect to either the missionary staff or the 'King' (the Aborigine, Menmuny) was severely punished. The Court, presided over by Menmuny, kept records and published a weekly black-list. Wife-beating was common among the non-mission Aborigines living in the Cape Grafton area. Gribble wrote of Aboriginal men beating their wives, which sometimes resulted in serious bodily harm to the women. One woman had had her arm crushed by a stone which her husband had flung at her, another had had her leg broken. ${ }^{31}$ Some men living on the mission continued to beat their wives but when discovered by Gribble the husbands would be either verbally chastised or given court sentences.

In spite of the segregation of the sexes during childhood and strict rules about their meeting, males and females did manage illicit time together. In order to get to know one another they had to resort to sending secret messages. A boy would send a letter to his girlfriend through either a village married woman or a girl on her way to do chores, or.

The boys would sneak into the girls' dormitory, through a window or something. A lot of them used to talk around the fence you know, in the night. But if they seen anybody like a missionary, or the men, they off.

You got to be very careful. You gotta sneak you know. You gotta sneak and talk or you get a hiding. If matron see they get a caning. We bin had those strict rule ya know. Discipline, eh. And this was old days. ${ }^{32}$

Once a couple wanted to get married and were of an acceptable age according to missionary standards, the boy approached the superintendent to request permission to marry. Once married, they left the dormitory and set up house in the married quarters, in a house built by the husband. A couple was married in the church and the wedding was celebrated in the dormitory, where the couple and their guests were given a supper by the missionary staff:

Dormitory had a spread. They go back there and have a good old feed, ya

know. Invite people. They have a spread and when you finish, you go now. ${ }^{33}$

Couples who were discovered sneaking time together were sometimes sent away to Palm Island, or if a girl became pregnant the couple had to undergo an experience of such intense shame that even today those directly involved do not like to speak about it. This was the 'ragtime wedding', when a couple were forced to marry immediately, with no-one present, have their heads shaved 'bawlie' (bald) and wear 'rags' (old clothes). There were no celebrations to mark their change of status from single to married persons:

Some of my mates they got married ragtime wedding. Their girlfriend fall into trouble, ya know. That's real common today. You can meet the girls any time you want to now... But them times, everyone get married from the dormitory. When you get married you leave dormitory. Everything all in strict order. I got married clear, ya know. Another couple my mates, they got ragtime wedding. No tea. Dormitory [non-ragtime] had a spread. They go back there and have a good old feed, ya know. Invite people... Not ragtime wedding. One of my poor old mates got married ragtime wedding.

They cut your hair you know... we used to get bawlie head too in the boys' dormitory... as punishment. Very seldom ya know, one time fifty years ago... very seldom you see a woman... ya know... pregnant like, in the

31 Ibid., 20 February 1893.

32 Mrs Tottie Joinbee, Cairns.

33 Mr Thomas Allen. 
dormitory. Soon as they... they get married straight away. Very seldom that bin happen in my time. 34

Adults had to obtain permission to marry, permission to work, and had no control over their own economy. Although some individuals entered the mission of their own accord, most had no choice. Those who rebelled against the rigidity and lack of freedom by trying to escape, were forcibly returned by police or other authorities.

\section{Escape, expulsion and exemption}

During the era 1892 to 1960 many people attempted to escape. One young boy ran away after he got a 'hiding with the Black Tom' (lawyer cane):

When we look across to the field over there where they keep the horses, $\mathrm{Mr}$ Iven $^{35}$ was hiding a boy with lawyer cane. And he was screaming his head off. And we could stand at the fence there. We was singin' out, but they couldn't hear us because we was over this way: 'don't hit that little boy!'. He flogged that little boy called Blue John, from Mossman. He run away. He stayed a few days till he feel all right, you know, from the hiding, then he ran away. ${ }^{36}$

Mr Iven, he cruel. When we seen him come to Yarrabah... we could see his face... the look of him you know. He had a little short wife and a dog called Jack Ivens. He used to lie on a couch on the verandah. With a cushion. Yeh. Jack Iven that dog. 37

Mrs Iven was a little short woman. You know them witches ya see? She was like a witch. I'm not telling ya a lie. That's what we used to call her. All the girls when we go over. She used to be that rough with us too. She was them kind of person look. You know, you see some lovely people eh, but you can see when a person is like what she was. ${ }^{38}$

Escape became an avenue for those who sought to control their own lives. The Cairns Post reported regular escapes from Yarrabah during the early part of the century. There were also reports of Aborigines who had run away from the mission because they were not getting enough to eat. 'Too much prayer and not enough tucker' was one man's comment. ${ }^{39}$ Aboriginal residents of Yarrabah were appropriately referred to as 'inmates' by the Protector of Aborigines ${ }^{40}$ delineating the restrictive institutional regime they were under. Escapes were usually unsuccessful; escapees were inevitably returned to the mission by police no matter how recalcitrant.

When police forcibly brought eight new arrivals to the mission in 1907, four of them absconded immediately in an attempt to rejoin the wives they had left behind. Some of the Aborigines who tried repeatedly to escape from the mission were sent to Kobahra, a settlement on nearby Fitzroy Island. In 1909 Fitzroy Island was still part of Yarrabah

34 Ibid.

35 Reverend W. Ivens, Superintendent of Yarrabah in 1910.

36 Mrs May Smith.

37 Ibid.

38 Mrs Tottie Joinbee.

39 The Cairns Post, 29 November 1910.

40 Queensland Parliamentary Papers, Annual Report of the Chief Protector of Aboriginals for the year ended 31 December 1919. 


\section{THEM DAYS}

mission land and had its own village with a coral and limestone church built by Willie Ambrym. 41

In September 1910, an Aboriginal couple walked the distance from Yarrabah to Caims and asked to be employed in Caims. They started work at the house of a Cairns resident but police took them in charge and handed them back to the Yarrabah authorities. In spite of their employer's plea to allow them to stay, they were returned against their will: 'the female aboriginal made pitiable appeals to be saved from her captors, but she and her husband were hauled back' 42

Some 'inmates' made vocal their protests about unsatisfactory conditions on the mission to any visitor who came. A constant complaint was the scarcity of food. When J.G. Appel, the Home Secretary, visited Yarrabah in June 1911, several people asked him for permission to leave. Every child that accompanied him and his party on their walk around the mission made the same request, that they be allowed to leave with them. Elderly residents at Yarrabah today (1985), who were very small children in the decade from 19101920 , remember 'them days' as 'starvation times':

We used to starve in that place. Green banana for dinner boiled. They boiled a green banana. We had three on our plate. We had com porridge for breakfast. Nothing else. Saturday - two girl have one coconut. She peel it and it's cut in half. She have half, I have half. That's a dinner, Saturday. And once a week meat. Leg. And they boil it in a big boiler. And they put so much rice in. That's all. You have that only once a week. 43

You couldn't get tucker like you get today. We used to live on treacle, home-made bread, and rice. They used to grow corn and the bread was made out of cormmeal. 44

Sometimes they had to find what they could in the bush during the day and were fed a meagre meal at night. The staple food was boiled bananas, combread, cassava, rice or sweet potatoes and black tea. One old woman who now lives in Caims remembers her arrival at Yarrabah in 1911:

She said to me, you wanta cuppa tea? Yes, please. You want something to eat? I said, whatya got? Treacle and bread. Oh, no thank you, I don't eat rubbish like that. You don't talk smart, tomorrow you'll be hungry, you'll eat anything. It a hungry place. Next day I was hungry all right. I had to eat anything after that.

I tell you. Used to be hungry. We girls used to get bones... rub it on the rock, just to get something out of it. You look some girl sitting on a rock hitting the bone, trying to get the marrow out... just to have something in your stomach. 45

Some ingenious methods were used as a means of escape. Two young Aboriginal women tried to escape on a raft they had built themselves from a few logs lashed together with vines. Passengers aboard the Kuranda saw the partly submerged raft in the Fitzroy

41 Gribble 1930:96.

42 The Cairns Post, 6 October 1910.

43 Mrs Tottie Joinbee.

44 Mr Thomas Allen. However, four of these years were during World War I, when the rest of Australia was also subjected to severe food restrictions.

Mrs Tottie Joinbee. 
Passage, between Fitzroy Island and the mainland and reported their sighting. The women were brought to Cairns and then sent straight back to the mission. 46

Expulsion and exemption proved to be other avenues of departure from Yarrabah, brought about by two diametrically opposite types of behaviour. Those who maintained strict adherence to mission rules could apply for exemption certificates. Upon being granted exemption certificates they could legally leave the mission to live in the outside world. Those who rebelled against mission rules and were found to be incorrigible, were eventually issued with removal orders; some were transferred to notorious Palm Island. ${ }^{47}$ Expulsion meant being sent to another reserve far from kin and friends - an effective means of disposing of rebellious elements likely to cause dissension and undermine mission rule.

In April 1915, six Aboriginal women, some with babies and small children, absconded from the Mission to Cairns but were detained by the police and summonsed. The Police Magistrate declared them liable, under the Act, to three months' imprisonment. They were sentenced to seven days' solitary confinement in the Cairns jail and the children were taken back to Yarrabah by the Mission Superintendent. That same month, another twenty-five people tried to run away from the mission. ${ }^{48}$ After this particular incident there were several letters to the editor of The Cairns Post protesting against the treatment of the 'blacks' and the mismanagement of the mission by the Church, some even proclaiming that the Act needed to be revised.

\section{Accusations of mismanagement}

Accusations regarding funding and mismanagement of the mission were constantly made between the three parties involved in its administration. The Government accused the Church of mismanagement, and the Church counter-accused the Government of not providing enough financial support and of using the mission as a penal settlement for incorrigible Aborigines. The 'inmates' unhappily were the pawns in the game, with no choice in policies made on their behalf.

Until 1908, the mission was almost wholly the personal project of Emest Gribble, who during his years at Yarrabah, gained help from the Australian Board of Missions, the Queensland Government and the Diocese of North Queensland. In 1908 the Church of England in Australia contributed $£ 610$ towards the support of the mission and the Government subsidy amounted to $f 571$; the Aborigines on the mission managed to raise £567 towards their own support, $£ 202$ of which was raised by the Yarrabah Brass Band while on tour in North Queensland. 49

In October 1910, R.B. Howard, Chief Protector of Aborigines, reported 'woeful mismanagement' of the mission during its entire existence; that

no real effort has been made to produce even medicine and food required to feed

the inmates. The want of efficient supervision is apparent in every direction. 50

Commenting on Howard's statement, the Archbishop of Brisbane declared that the mission existed:

46 The Cairns Post, 26 October 1911.

47 Rosser 1977.

48 The Cairns Post, 19 April 1915.

49 Gribble 1930.

50 The Cairns Post, 27 October 1910. 


\section{THEM DAYS}

for the purpose of raising the blacks to a higher moral and spiritual level, and what might seem mismanagement from a purely industrial standpoint might be entirely right and proper management if the higher view was taken. 51

The Archbishop accused the Government of not providing a large enough grant to cover even the cost of feeding the mission residents. He insisted that the Government, and not the mission, should pay for the feeding and clothing of the Aborigines.

In 1911, a Yarrabah Management Committee was set up in Brisbane, appointed by Dr Donaldson, the Archbishop. At this period, the Queensland Government supplied $£ 770$ per annum, and the Australian Board of Missions $£ 850$ per annum. With the continuing disagreement between Government and Church authorities as to who was ultimately responsible for the welfare of the mission Aborigines, another possibility was considered: that Yarrabah might be converted by the State into an industrial settlement, possibly based on the bêche-de-mer industry. This suggestion was indignantly received by the Bishop of North Queensland, who thought it inconceivable that a Christian government would turn a Christian mission into an industrial settlement, or force the Anglican Church to voluntarily vacate Yarrabah. 52

However, the Bishop held a meeting which was attended by about one hundred and thirty Yarrabah Aborigines, to discover what the Aboriginal people felt about the idea of Yarrabah becoming an industrial settlement. He couched his address in terms which left his audience in no doubt that the Bishop's view of industrialisation was negative. At the end of his address, James Noble, the Aboriginal clergyman and a convincing orator, spoke against industralisation, moving that the settlement should remain as it was: under Church authority.

The people of Yarrabah were then asked to express their opinions about the possible change. In light of the statements made by the Bishop, and by James Noble, one hundred and ten Aborigines present at the meeting said that they wanted no change; only twelve people wanted change. The minority who voted for change were all men from Fraser Island, some of whom subsequently requested to be transferred to the Government settlement of Barambah (later Cherbourg). Their request was granted. The choice was not to stay or leave the reserve system, but only to stay or move to another reserve.

Aborigines who remained at Yarrabah, by choice or by force, could follow the rules; perform small acts of rebellion; learn subversive techniques to acquire a certain degree of personal autonomy; try to enlist help from outside agencies; or sink into apathy. Few other choices remained. Morris ${ }^{53}$ writes that the Dhan-Gadi's (Macleay Valley) attempts to resist the inculcation of white values during the era 1936-68 resulted in a 'culture of resistance', and emerged as a conjunction of earlier cultural practices and opposition to European control. This resistance was expressed by denial, distancing and evasion of European authority. Because overt strategies of opposition, such as violent acts of rebellion, resulted in people's being physically removed from the station, the form of resistance became more subtle. Non-violent forms of resistance were used; these included the control of information, illegal drinking and gambling, and the establishment of fringe camps free from institutionalised control.

\footnotetext{
51 Ibid.

52 Ibid., 11 May 1911.

53 Morris 1988:33-63.
} 
Yarrabah closely approximated the 'total institution'. 54 The functions of various institutions such as accommodation, education, and health - dispersed in the wider society were centralised within the mission station. The priest/supervisor made all the decisions regarding both the spiritual and the secular management of the lives of residents. Deference to his authority was expected, indeed insisted upon. Institutionalised Aborigines could be searched at any time, had their property confiscated, their mail read, their children confined to dormitories and their traditional practices prohibited. The following conversation between two elderly ex-residents ${ }^{55}$ of Yarrabah, who are now in their eighties, recalls these restrictions:

T: I asked her [M] to write me, I want get some tucker from my people [white foster parents off the reserve]. And I said, M, here's a envelope, and there's writing pad will you write to my people? So I write to my Mum, I said, 'I want milk, I want sugar' - we used to get everything in tins, tin milk - 'I want sugar, I want porridge'. I said 'I'm hungry... I want something...'

M: I put 'em all down.

T: This one [M] put 'em all down. I said 'how I'm gonna post it. I can't give it to Mr L. [the supervisor] he goin' to read it. I gonna give it to the skipper.

M: One of the boat boys.

T: I don't know how. You can give it to somebody. And they send that letter. They posted it for me. I had a big sack of food come for me. The next week. That fella post it.

I take it out. You know that big tin they call London Mixture. That was full of all kinda lollies. I gave everyone a little taste of everything I had in that bag. A couple of months after that, they [foster parents] wrote and I had a letter edged in black. I said, 'oh, my mum's died'. She died in Cairns hospital with cancer. Told me in the letter. And in that letter that come to me: 'I'm sending you...' might be say, money, but that all cut out. Superintendent cut that out. They keep that money. They use it for themselves.

There is no doubt that life under a mission regime was strict and disciplined. Letters were censored, and communication between residents and those outside was carefully controlled. Aborigines could be ordered to work on mission tasks up to thirty-two hours a week without remuneration. People who were Aboriginal or 'half-caste' or (for some provisions) those with any degree of Aboriginal descent, were placed under the protecion of 'the Act'.56 Queensland reserves became repositories for Aboriginal criminal offenders or any Aborigines considered a threat to the white community. 57 Released Aboriginal prisoners began to be sent to Yarrabah, along with 'incorrigibles' from other stations in the north.

Some women came voluntarily, for the schooling and protection offered by the mission, but most were there involuntarily, perhaps because of aborted liaisons with nonAborigines - women who had been sexually used by men on bêche-de-mer boats and dumped

54 Goffman 1961

55 Mrs Tottie Joinbee and Mrs May Smith, residents of Cairns.

56 The Aborigines Protection and Restriction of the Sale of Opium Act (Queensland) 1897.

57 Reynolds 1978:165. 


\section{THEM DAYS}

ashore at different places along the Queensland coast when the men grew tired of them; or women who were pregnant to married men and therefore an embarrassment. One 'half-caste' woman from Port Douglas wanted to join the mission but Gribble refused her because she said she was a Roman Catholic and could not attend the Anglican Church.

The Protestant work ethic prevailed amongst early missionaries and other Europeans of the times. The aim of the missionaries was civilisation, being defined as the value systems and work patterns of Europe at that time, and Christianity in Western terms. The 'natives' were seen as indolent and until they could learn what hard work was, they could never become Christians. Work seemed to be the one avenue which would 'save' the Aborigines. Reverend W.I. Ivens, superintendent of Yarrabah in 1910, in his discourse at St Andrews Church in Sydney before leaving for the mission, stated:

In these reservations people must be made to work, and in work lay the ultimate hope of the preservation of the Aborigines. There was no reason why they should not be preserved. It was necessary that they should come under discipline. Success had already attended the efforts in this direction.

Success in the mission lay in the separation of the people from their surroundings. If any of these people were brought into towns or cities they were bound to go down. They had not behind them, as was the case with their white neighbours, centuries of civilization. So the people must be taken away from the towns and put into reservations. 58

With the notion that work and Christianity went hand in hand, it can be understood why the 'natives' might misinterpret a hymn taught to them in pidgin English by Gribble: 'Shall we gather at the river?' In the second verse, instead of singing 'We will walk and worship forever', it became 'We will work and wash up for ever'. ${ }^{59}$ Perhaps they had learnt their lesson well.

In 1939 when the 1897 Act was repealed and replaced by the Aborigines Preservation and Protection Act, and the Torres Strait Islanders Act, no real legislative changes occurred. The rubric 'Chief Protector' became 'Director of Native Affairs', but a change in title did not mean a change in the system. The new Act was as oppressive as the 1897 Act. District Protectors and Reserve Superintendents remained. The Director could still remove Aborigines to and from reserves (Section 22), and no Aborigine could leave a reserve, settlement or mission, even for a short time, without the permission of the Protector, Superintendent, or other authorised officer (Section 23). Permission had to be obtained from the District Protector for marriages between Aborigines. Superintendents could prohibit card games, dancing and 'native' customs, order residents to do thirty-two hours of work without payment, and control their bank accounts. They could also inflict corporal punishment. With the approval of the Director, a Protector or Superintendent could order any letters or mail addressed to or written by Aborigines to be opened and perused by him or some other officer deputed by him (Section 32). The new Act spelt out in even greater detail than the 1897 Act provisions for running reserves, while at the same time retaining the former provisions designed to protect Aborigines against exploitation by employers.

Under the 1939 Aborigines Preservation and Protection Act Aborigines believed to be sufficiently Europeanised could be exempted from the conditions of the Act. ${ }^{60}$ To obtain an exemption certificate a person had to be 'half-caste and civilised' and have no intercourse with Aborigines, and then only on satisfying the Department of Native Affairs of his

58 The Cairns Post, 4 August 1910.

59 Gribble 1930:99.

60 Fitzgerald 1983:509. 


\section{ABORIGINAL HISTORY $1991 \quad$ 15:1}

ability to manage his own affairs. Once a person was exempt from the Act he was not allowed to live on a mission or settlement. So in order to be granted an exemption certificate, the exemptee had to cut himself off from further contact with all those members of his family who were not exempt, or who were still living on a mission or reserve.

An ability to manage their own affairs and acceptance of the rule of no contact with other Aborigines, still did not ensure that an exemption certificate would be granted to those who applied. In 1932, forty-two applications for exemption were received in Queensland but only fifteen were granted after careful investigation of the claims as regards the character, education, intelligence and 'breed'. 61

In 1933, Bishop Dixon, Assistant Bishop of Brisbane, spoke out on the poverty of material conditions at Yarrabah, and suggested that the mission be handed over to the Government. In August that year the Chairman of the Australian Board of Missions accepted the resignation of the Yarrabah Committee at Brisbane and agreed to the transfer of the management of Yarrabah mission to the Diocese of North Qucensland. Members of the Australian Board of Missions were strongly of the opinion that the management of the mission should be vested in a Committee at Townsville rather than solely in the Bishop of North Queensland, and that such a Committee should be nominated by the Province of Queensland. However, Yarrabah did not come under the control of the Bishop of North Queensland at this time. There was a lot of ill-feeling between the Bishop and the Superintendent at Yarrabah (in 1933 this was McCullough); the latter was continually left uncertain about his future at the mission. 62

A lot of correspondence passed between McCullough and Canon John Stafford Needham, Chairman of the Australian Board of Missions in Sydney. McCullough pointed out that as a lay superintendent he had always been particularly careful never to interfere in the religious side of the mission. The Bishop of North Queensland nevertheless insisted that a member of the clergy should be superintendent and in March 1935, Needham wrote to McCullough advising him that he would no longer be superintendent. There had been a board meeting and a new management committee had been set up. Its members were the Archbishop of Brisbane, the Bishop of North Queensland and the Chairman of the Australian Board of Missions ex officio. The Bishop had won his case.

That same month (March 1935) the Queensland Government sent a Commission of Enquiry to investigate the care and treatment of Aborigines in various settlements and missions. By May 1935, Palm Island was closed to fresh admissions except diseased Aborigines and Yarrabah was taking its place as a penal settlement. Because of the large Government subsidy given to Yarrabah it could not refuse entry to persons sent by the Government. McCullough was extremely concerned about the image of the mission to the general public; he suggested to Needham that it was now time for the Government to assume full responsibility for Yarrabah. To Aborigines in outback Queensland, the name 'Yarrabah' was equated with 'prison'. Despite this image, the Brisbane Committee instructed McCullough to keep no one at Yarrabah against his will. McCullough said that he had always told anyone who desired to leave that he could go if he liked, but that practically no one had left during his years as superintendent.

Any superintendent of Yarrabah was in the unenviable position of having the Committee Treasurer tell him to 'keep costs down as funds were low' while the 'inmates',

61 Queensland Parliamentary Papers, Annual report of the Chief Protector of Aboriginals, 1932.

62 ABM Archives, Letters 1930-1935, between Superintendent McCullough and Needham, Chairman of ABM from 1922-1942, Box 1, Series 1, Folder 2. 


\section{THEM DAYS}

public, and various government officials accused him of starving the people. The cost of running the mission was always more than the funds available. The existence of the mission was continually endangered because of insufficient finance and lack of qualified personnel, even though everything possible was done by the staff to keep things going (sugar mills were canvassed to donate free sugar, attempts were made to grow cotton and agricultural products, and sand was analysed for minerals). Between 1937 and 1947 the cost per annum of running the mission increased from $£ 4,700$ to $£ 19,935^{63}$ and the mission was continually in debt.

\section{0-1950: the War and its aftermath}

It was not until the 1940 's, during the second World War, that events in the wider world began to influence the Aborigines in Queensland to any significant extent. Aboriginal labour was necessary to replace the European Australians who were fighting overseas. These years gave Aborigines an insight into European society as well as greater confidence in their own abilities. The War years are regarded by some of the Yarrabah people as a time when things came together for Aboriginal people:

When the second World War started, everything came better for us see. They were short of labour in the cane field so they had to pull us outa there [Yarrabah]. Outa the mission ya know. They couldn't get any other people. All the Italian farmers, most of them was unnaturalised. They had to take 'em away to get intern ya know. I remember I was cuttin' cane in Mossman there. 1941, when the war started here. We come out for the week and go back every weekend. Go back to Yarrabah.64

Yarrabah Aborigines were working on the Atherton Tablelands harvesting peanuts, cowpeas and maize. The majority of Aborigines employed throughout the state worked in the pastoral industry. Although the gangs were supervised by European overseers of the Department of Native Affairs, this was an opportunity for Aborigines to prove their capabilities in the white man's arena. During the five years of the War, exemptions averaged one hundred per year throughout Queensland. In 1946 the number of exemptions was one hundred and thirteen, and 3,500 Aborigines were employed in jobs that Europeans normally occupied. ${ }^{65}$ Wherever there was a shortage of white labour, Aborigines were called upon. A great improvement in conditions for Aborigines was that they were paid award wages. The labour supplied by Aborigines recruited from church missions and government settlements saved the pastoral industry in Queensland during the war years, a fact admitted by the Department of Native Affairs. ${ }^{66}$ In 1948, there were two hundred Aborigines cutting cane in the Ingham area and further north. Exemptions in 1948 numbered one hundred and eleven throughout the state.

The 1950s: problems and tensions over management

By December 1950 the population of Yarrabah numbered six hundred and ninety-five. Despite an increasing population, funding for the running of the mission remained inadequate. In the decade 1950-1960, when public criticism of the management of the mission was high, a Government handover was often discussed. The Cairns Post reported

63 ABM Archives, Southcott 1984:5.

64 Thomas Allen.

65 Queensland Parliamentary Papers, Annual report of the Director of Native Affairs, 1944.

66 Ibid., 1946. 
constant problems and tensions at Yarrabah, and controversies over the management of the mission. In the latter half of the 1950's Yarrabah required a staff of 15 or 16 people, and cost approximately $£ 1,000$ a week to maintain. ${ }^{67}$ There was a high turnover of priests and staff; sometimes the position of superintendent was held by a resident priest, at other times the superintendent was not a member of the clergy. Between 1954 and 1960 Yarrabah was even without a priest for two and a half years. This decade was a time of rapid change and one in which Aborigines began to take more positive action towards change.

The 1950's saw many individuals from mission stations throughout Queensland moving off the reserves for schooling. At Yarrabah, more children were attaining higher levels of schooling and more exposure to living in an off-mission environment by attending outside schools. Few children in the early part of this decade attained an educational level beyond grade three, in spite of the fact that grades four to six nominally existed. But by 1956, many children were reaching grades five and six before fourteen years of age. Boys who attended school after age fourteen were given one shilling per week, the same as trainee boys, in an effort to encourage them to remain at school and continue their education. By 1958, many children were reaching grade seven.

Recreation and entertainment improved during the 1950's. Full cinema programs were shown each week from 1956 and playground equipment was donated. Living standards improved with new timber frame houses and WC's, weatherboard houses with galvanized roofing replaced sub-standard houses. Free milk was delivered to schoolchildren. A weir and irrigation pipes to farms were constructed; a jail block and compound were completed.

Despite the apparent improvements in education and living standards - improvements in a Western sense - the Yarrabah people still did not control their own lives, nor have any real input into decision-making. Permission still had to be obtained for even the fundamental rights of obtaining employment, leaving the Reserve, and getting married.

Off-Reserve employment during the War years had enhanced the self-image of Aboriginal workers and had given them more insight into the possibility of being able to survive independently in the wider world. By this decade, many had already left the mission while others were working outside. Mission authorities were complaining that they did not have enough 'able-bodied men' to perform the heavy labour necessary to keep the mission going. Men employed outside usually lived in bachelor barracks on the work site. Their wives and children stayed behind at the mission. If a man decided to leave his job for any reason he had to notify the superintendent; if he left and could not be found, the superintendent would get the police to search for him and return him to the mission.

People working in seasonal occupations returned to the mission during the wet season. These workers looked upon their between-season stays as a holiday - an attitude which did not please mission staff. However, it is not surprising that the seasonal workers maintained this attitude on their return as, upon resuming mission work, they were repaid only by rations for the first thirty-two hours' work, and a few shillings cash for a subsequent eight hours' labour. Men were employed as carpenters, farm hands, policemen, storeworkers, and in fencing and general maintenance. Some people were employed on wages but only if the superintendent considered their service adequate. He could, at his discretion, take workers off wages should their work prove unsatisfactory, and give them rations only.

In 1953, farm workers at Dijinghi Settlement, an outstation of Yarrabah, requested either an increase in wages or an increase in rations. Upon consideration of this request the Yarrabah Committee decided only to make a redistribution of rations to suit the workers. In 1955, the Yarrabah Committee felt that Aborigines on rations should in accordance with

67 Shevill 1966:80. 


\section{THEM DAYS}

government regulations, continue to work thirty-two hours a week for rations and those being paid should work forty hours a week. 68

By the mid-1950's residents were becoming increasingly dissatisfied with the way they were being treated at the mission. Behaviour that Gribble would have regarded as serious misconduct to be severely punished, was now not serious enough to warrant a Removal Order. Repeated 'misdemeanors' (such as adultery and petty theft) prompted requests by the Yarrabah Committee to the Director of Native Affairs (DNA) for Removal Orders, but the DNA refused to issue Removal Orders on these grounds.

In 1956, a group of Yarrabah men decided to take positive steps to alter their position. These men were working in the cane fields outside and had been discussing their situation with members of the Trade and Labour Council in Caims. It was decided that a visit should be arranged for the Council members to visit the mission in order to inspect the working conditions there.

In 1957 Union delegates were given permission to visit Yarrabah without the superintendent's knowledge of their association with the Trade and Labour Council. Following this visit allegations were made in the local newspaper about the poor conditions at Yarrabah. An article in The Cairns Post ${ }^{69}$ reported that:

conditions at Yarrabah were appalling; the sanitation was not good, a lighting plant was in operation but lights were only installed in staff quarters and street lights were only in administration areas; Aboriginal homes were extremely depressing and dilapidated with neither furniture nor cooking facilities. Men had to work 32 hours a week for the right to rations, and had to work an extra eight hours above the 32 hours in order to earn nine shillings and sixpence a week. Discipline was contrary to all concepts of British justice.

In spite of this report, the Yarrabah Committee felt that these allegations could be ignored because they were neither directed at, nor detrimental to, the Church. However, as a result of this incident the mission staff decided that the general public would not be admitted to the mission except during the general tourist season.

While only two exemption certificates were granted to Yarrabah people in 1955, and nine (three families) in 1956, between 1957 and 1959 there was a large exodus of residents from Yarrabah. Exemptions had been possible under legislation since the 1939 Act, but not many had been granted. Permission for exemption still had to be obtained from the Director of Native Affairs with the approval of the superintendent. However, in the 1950's with allegations of mismanagement, increasing financial difficulties faced by the Church, and Aborigines themselves pressing for change, more applications for exemption were being received and the Church's policy became 'schooling people for exemption'. ${ }^{70}$ People were sent out for short-term employment then returned to the mission. When they appeared capable of self-support and self-control a job was found for them. If the man were married, the job would be one which would provide for himself and his family, at which time an exemption certificate was granted for the man, his wife and their children. ${ }^{71}$ By 1958 exemptions were given to as many people as possible with the goal of eventual

68 ABM Archives, Minutes of the Yarrabah Committee Meeting, 14 February 1955, Box 2, Folder 5 .

6918 October 1957.

70 ABM Archives, Superintendent Wilcox's report to ABM, December 1958, Box 1, Folder 4.

71 ABM Archives, Minutes of the Yarrabah Committee Meeting, 4 December 1958, Box 1, Folder 6 . 
assimilation of the whole population. The 1939 Act remained in force until 1965 when the Aborigines and Torres Strait Islands Affairs Act was passed.

A letter from Wilcox, the Yarrabah Superintendent in 1958, to Father Coaldrake, Australian Board of Missions, Sydney, dated 20 November 1958, indicates he was overwhelmingly in favour of the Church's handing the mission over to the Government. His main reason was that, in spite of their unsparing efforts to secure staff when needed, the Church was not able to supply enough staff, or staff with the right qualifications, who were willing to stay at the mission for any length of time. The major problem for the Church was that it had to administer both law and grace. To enforce law meant that the Church became unpopular, defeating its aims of making any progress in the spiritual domain. In a letter dated 6 December 1958, ${ }^{72}$ Bishop Ian Shevill (North Queensland Diocese) wrote to Coaldrake at Australian Board of Missions, Sydney, to the effect:

I think that after fifty years battling with insufficient money and insufficient men, the policy of this Diocese and the Yarrabah Committee would be to give the Mission back to the Government with grateful hearts if they would accept it.

At the end of 1959 it was agreed that the Government should take over the temporal control of the mission, but that the spiritual needs of the people should be the sole responsibility of the Anglican Church, the Chaplain to be appointed by the Bishop of the North Queensland Diocese, and paid by the State through Church channels. After being run in turn by the Gribbles, the Australian Board of Missions and the Diocese of North Queensland to this point, the Government was to take control for the next twenty-five to twenty-six years. It was believed that after this period, following a policy of assimilation, there would no longer be the need for a mission at all.

In 1960, the Queensland Government initiated legislation which ultimately removed all missions in the state from the Churches and into its control. Thus, as of 1 July 1960, the Government managed and funded Yarrabah and became responsible for the material and social welfare (health and education) of its residents. The Diocese had exclusive spiritual rights, and the Australian Board of Missions, freed of any further financial responsibilities, was to retain the right to suggest suitable personnel.

\section{Summary}

This paper has given an historical account of Yarrabah mission from 1892 to 1960 . It has shown the various choices open to Aboriginal people living on the mission, the constraints they were forced to suffer while living within a white-dominated social system, and the actions they took in response to these constraints. During this epoch there was a change in the strategies used by Aborigines, as well as a change in the views of the white majority towards Aborigines. The early Government policy of isolating Aborigines from the rest of the population, legislated by the Aborigines Protection and Restriction of the Sale of Opium Act of 1897 (later repealed and superseded by the Aborigines Preservation and Protection Act of 1939) enabled the missionaries to gather together recruits. Both Church and Government policy reinforced each other in their notions of protection for Aborigines. A paternalistic policy of protecting Aborigines from their own and others' vices, as well as protecting the purity of the white race, ensured ease of gathering recruits for the mission. It was thought that Aborigines, particularly 'half-castes', would be better off on isolated mission stations and reserves. Inmates who attempted to change or evade the system by rebellion or escape, were constrained by being removed or forcibly returned.

72 ABM Archives, Letter of 6 December 1958 from Shevill to Coaldrake, Box 1, Folder 4. 
Thus, within a protective framework, action on the part of the Aborigines was systematically suppressed.

Visitors to the mission at various times discovered that conditions for the residents were far from idyllic in spite of the fact that Yarrabah was purported to be a model mission. Newspaper accounts made the general public more aware of the plight of Aborigines and, over the years, Aborigines themselves were able to publicise their position. Mission management altered over time, and mission personnel continually changed after Gribble left. Ill feelings between secular management and sacred authority did not promote a smooth-run administration for the mission; as well, financial problems in managing the mission exacerbated personnel clashes. A growing population of Aborigines, rather than a disappearing race, was making the notion of smoothing the dying pillow more and more remote.

Outside employment made Aborigines more conscious of what life off the mission was like, and undoubtedly made them more aware of the differences between their own situation and that of non-Aborigines. In the War years of the 1940's, when Aboriginal men were desperately needed to fill jobs normally undertaken by European males, it became obvious that they could in fact take their place as workers alongside Europeans.

Growing discontent with the mismanagement of the mission in the 1950's, and more public sympathy toward their plight, made it easier for Aborigines in this decade to take action to effect radical change. By this time, escape, expulsion and exemption had all been tried, not without results, but in the decade 1950 to 1960 , residents were able to more effectively express their discontent with the system and bring about a desired change. In this decade also, there was more outspokenness on the part of Aborigines in other areas of Australia, better education, and a Government policy of assimilation. Internal dissension occurred simultaneously with a growing concern by mission management with the ineffectiveness of the entire Yarrabah system.

Change was inevitable, but there were a number of factors, rather than any isolated incident, which resulted in the collapse of Church authority and the Government takeover. Internal changes, in the form of Aboriginal action, occurred at the same time as the breakdown of the mission structure. Both events contributed to the changes of the late 1950's.

In spite of some of the gruesome stories that are recounted by the old people today, some reflect about life in the early days on the mission as 'the good old days'. Seen in the light of today's seemingly anarchic disorder, ${ }^{73}$ present-day elderly residents look back on the past as a time of order, control and non-violence. Selective memory often eliminates unpleasant incidents and evokes times past as halcyon days. When the 'ole gels' [older women] get together today they express a sense of camaraderie and solidarity as they reminisce about shared past experiences. On reminiscing, some remember those days as being 'wonderful'; others look back and recognise the physical restrictions and sometimes cruelty imposed on them.

\section{Acknowledgments}

Funding for this research was made possible by a scholarship from the Commonwealth Department of Education, a grant from the Australian Institute of Aboriginal Studies, and the Department of Anthropology and Sociology, University of Queensland. I would like to thank Dr Ian Keen for comments on earlier versions of this paper, when it was in thesis form. I would also like to thank the Department of Anthropology, University of Calgary,

73 See Hume 1988:254-258. 
for providing assistance to me, and the Yarrabah Community Council for permission to work on the Reserve.

\section{BIBLIOGRAPHY}

Australian Board of Missions Archives, Sydney. Boxes 1, 2: MS 1515/1; MS1515/2. . Margaret Southcott, 'A guide to the Chairman of the Australian Board of Missions' correspondence relating to Aborigines 1891-1976.' Unpublished MS, 1984.

Brady, Maggie and Kingsley Palmer. 'Dependency and assertiveness: three waves of Christianity among Pitjantjatjara people at Ooldea and Yalata', in Tony Swain and Deborah Bird Rose, eds., Aboriginal Australians and Christian missions. Bedford Park, 1988.

The Cairns Post, 4 August 1910; 6 October 1910; 27 October 1910; 29 November 1910; 11 May 1911; 26 October 1911; 19 April 1915; 18 October 1957.

The Diocese of North Queensland Yearbook, 1959-1960.

Feetham, J.O. and W.V. Rymer eds. 'Aboriginal Missions', in North Queensland Jubilee Book 1878-1928. Townsville, 1929.

Fitzgerald, Ross. From 1915 to the early 1980s: a history of Queensland. St. Lucia, 1983.

Gilbert, K. Living black: blacks talk to Kevin Gilbert. London, 1977.

Goffman, E. Asylums. Harmondsworth, 1961.

Gribble, E.R. Forty years with the Aborigines. Sydney, 1930. . A despised race. Sydney, 1933.

Harris, John. 'North Australian Kriol and the Kriol "Holi Baibul"', in Tony Swain and Deborah Bird Rose, eds., Aboriginal Australians and Christian missions. Bedford Park, 1988.

Hume, Lynne. 'Christianity full circle: Aboriginal Christianity on Yarrabah Reserve', in Tony Swain and Deborah Bird Rose eds., Aboriginal Australians and Christian missions. Bedford Park, 1988.

Morris, Barry. 'Dhan-gadi resistance to assimilation', in Ian Keen ed., Being black. Canberra, 1988.

Queensland Parliamentary Papers. Annual report of the Chief Protector of Aborigines. 1919. $1920,1932$. Annual report of the Director of Native Affairs. 1944, 1946.

Reynolds, H. ed. Race relations in North Queensland. Townsville, 1978.

Rosser, B. This is Palm Island. Canberra, 1977. Dreamtime nightmares: biographies of Aborigines under the Queensland Aborigines Act. Canberra, 1985.

Rowland, E.C. The tropics for Christ. Townsville, 1960.

Shevill, Ian. Half time. Brisbane, 1966.

Swain, Tony and Deborah Bird Rose eds. Aboriginal Australians and Christian missions: ethnographic and historical studies. Bedford Park, 1988.

Trigger, David S. 'Christianity, domination and resistance in colonial social relations', in Tony Swain and Deborah Bird Rose eds., Aboriginal Australians and Christian missions. Bedford Park, 1988.

Walkabout, 1 July 1955.

Wandandian (Richard Dyott). Travels in Australasia. Birmingham, 1912. 